\title{
The influence of solar activity on the formation of plant phytomass in dry steppe conditions
}

\author{
Karine Trubakova*, Svetlana Turko, and Marina Vlasenko \\ Federal Scientific Centre of Agroecology, Complex Melioration and Protective Afforestation of the \\ Russian Academy of Sciences, Universitetskiy ave. 97, Volgograd 400062, Russia
}

\begin{abstract}
The main mechanism for the formation of yield is the process of transpiration, the driving force of which is the radiation balance and photosynthetically active radiation (PAR). The larger the area of the plant surface that receives the luminous flux of solar energy, the more active the action of the photosynthetic process. The formation of organic matter depends on the formed aboveground phytomass of plants. The aim of the study is to find the optimal ratio between the emitted flux of solar energy and the area of the assimilation apparatus for further determining the phytoproductivity of plants. The object is located in the steppe zone of the central part of the Volgograd region (southern part of the Volga Upland, $48^{\circ} 38^{\prime} 52^{\prime \prime} \mathrm{N}, 44^{\circ} 26^{\prime} 14^{\prime \prime}$ E). Modern methods of mathematical processing of experimental data were applied. The duration of the growing season of plants and the amount of light exposure affect the optical density coefficient $\left(K_{\mathrm{od}}\right)$. As a result, the coefficient $\left(K_{\mathrm{PAR}}\right)$ should be close to 1 unit for use $2.5 \%$ sunlight radiation (PAR).
\end{abstract}

\section{Introduction}

The phytoproductivity of vegetation depends on many factors, including the properties of the nutrient medium, weather conditions, moisture reserves in the soil, taking into account its consumption during the growing season [1-4]. Solar radiation is one of the factors that affects it during the growing season [5]. This activity is not only an energy resource. It has a strong regulatory (signaling) effect on plants. For example, sunlight determines such phenomena as photoperiodism, phototropisms, photomorphogenesis, etc. The indicator of solar radiation changes with the depth of penetration into the canopy of plantations [6-7]. The luminous flux density decreases with distance [8-9]. The vectors of change in the light load and the area of the sheet apparatus are polar. This fact assumes the presence of an optimum in the ratio of sunlight and leaf surface for maximum plant productivity and the simultaneous influence of these vectors. The activity of the photosynthesis process depends on the intensity of the light flux [10].

\footnotetext{
* Corresponding author: trubakova.karine@mail.ru
} 


\section{Materials and methods}

Observational materials on the study of the effect of sunlight on the phytoproductivity of sown cenoses, obtained on the territory of the dry steppe of the Volgograd region $\left(48^{\circ} 38^{\prime} 52^{\prime \prime} \mathrm{N}, 44^{\circ} 26^{\prime} 14^{\prime \prime} \mathrm{E}\right)$ were used and processed. Plant phytoproductivity is calculated as the increase in plant mass per unit area. The calculation of the optimal ratio of factors influencing the formation of the herbage was carried out. The dependence of the productive component on the coefficient of optical density of the plant community $\left(K_{\text {od }}\right)$ was established. The average values of the radiation balance and PAR on the example of winter wheat and the dependence of its yield ( $\mathrm{t} / \mathrm{ha}$ ) on the coefficient of optical density of the plant screen $\left(K_{o d}\right)$ were determined. he phases of plant vegetation were taken into account. At the beginning of the growing season, the leaf apparatus is underdeveloped and soil moisture is released into the atmosphere through physical evaporation. The transpiration moisture exchange begins with an increase in the leaf area. It determines the phytoproductivity of plants. The physical evaporation due to an increase in the density of the vegetation screen to decrease [11-12].

\section{Results and discussion}

The coefficient of optical density of the plant community $\left(K_{\mathrm{od}}\right)$ depends on the duration of the growing season and on the total light load. There are two values of the coefficient of optical density $\left(K_{\mathrm{od}}\right)$ : at the beginning and at the end of the growing season. At the beginning of the growing season, there is enough sunlight for the plants to absorb, but the receiving surface is not enough. At the end of the growing season, plant development is suspended due to weak sunlight activity. We get two vectors of the biological process. The coefficient of optical density varies from 0.01 to 0.33 for the Volgograd region.

The deeper the light flux penetrates into the plant canopy, the more it changes. When determining the light load in the plant community, it is allowed to use the average point values of the light load. The vegetation space is considered anisotropic, the coefficient of optical density does not depend on spatial coordinates. The change in the light load in the vegetation screen is considered proportional to the transparency of the screen.

There are two options for defining the transparency of the vegetation screen. This main one:

$$
\phi=\left(1-K_{o d} \ln \left(\frac{X+B}{B}\right)\right)
$$

$\varphi-$ a transparency of the vegetable screen (in shares);

$X-$ a depth of penetration of sunlight into the vegetation screen, $\mathrm{cm}$;

$B$ - a coefficient for the plant screen (1 unit).

The second option has a dependency:

$$
\phi=e^{-K X}
$$

$K$ - a density factor of the vegetation screen;

Light load in the plant screen:

$$
I_{a}=\frac{1}{h} \int_{0}^{h} I_{0}\left[1-K_{o d} \ln (X+1)\right] d x
$$


$I_{0}$ - a density of the luminous flux on the way to the plant screen, during the growing season;

$h$ - a grass stand height, $\mathrm{cm}$;

$K_{\text {od }}$ - a coefficient of optical density of the vegetation screen.

The equation and taking into account the conditions are solved:

$$
I_{a}=I_{0}\left\{1-K_{o d}\left[\frac{h+1}{h} \ln (h+1)-1\right]\right\}
$$

$I_{\mathrm{a}}$ - an average value of light load in a plant community with a herbage height $(h), \mathrm{cm}$.

The component influencing the plant phytoproductivity has been determined. It is necessary to determine the value that perceives this light load by the aboveground phytomass. It is related to the coefficient of optical density of the plant screen and depends on the properties of the plant community and on the light load of the region and the growing conditions of the herbage. $K_{\text {od }}$ must be disclosed. The productive component is equal to:

$$
q_{p}=I_{a} \cdot K_{o d}
$$

$q_{\mathrm{p}}-\mathrm{a}$ biomass formed in the plant community, c/ha.

A similar scheme is used to calculate the phytoproductivity of cereals, only instead of $K_{\text {od, }}$, the coefficient of use of light load is calculated $-K_{\mathrm{PAR}}$ :

$$
q_{p}=\frac{I_{a} \cdot K_{P A R}}{100 \cdot K_{c}}
$$

$K_{\mathrm{c}}-$ a calorie content of $1 \mathrm{~kg}$ of plants, cal/ha;

$K_{\mathrm{PAR}}-$ an absorption coefficient of sunlight.

In this dependence, $K_{\mathrm{PAR}}$ is $2.5 \%$. This indicator depends on the conditions of the place and the year of plant growth. $I_{\mathrm{a}}$ value depends on the transparency of the vegetation screen.

Improving the dependence by introducing $I_{\mathrm{a}}$ and the coefficient $N_{\mathrm{c}}$ :

$$
\begin{gathered}
q_{p}=\frac{I_{a} \cdot K_{P A R} \cdot N_{c}}{100 \cdot K_{p}}, \\
N_{c}=\left[1-b_{1}\left(\frac{\Delta T}{T_{o p t}}\right)\right]^{2}\left[1-b_{2}\left(\frac{\Delta W}{W_{o p t}}\right)^{2}\right]\left[\frac{N}{N_{o p t}} \cdot \frac{P}{P_{o p t}} \cdot \frac{K}{K_{o p t}}\right]^{m}
\end{gathered}
$$

$N_{\mathrm{c}}$ - a rate coefficient;

$\Delta T, \Delta W$ - a deviation of air temperature and moisture reserves in the soil from optimal values $-\Delta T_{\mathrm{opt}}$ and $\Delta W_{\mathrm{opt}}$;

$N, P, K-$ a the actual content of nitrogen, phosphorus and potassium in the soil;

$N_{\text {opt }}, P_{\text {opt }}, K_{\text {opt }}-$ an optimal content of nitrogen, phosphorus and potassium.

The problem boils down to finding values for the $N_{\mathrm{c}}$ coefficient by years.

It is necessary to have three $K_{\text {od }}$ and grass heights to express the role of sunlight. Based on the allometric growth law:

$$
\frac{d K_{o d}}{d h}=\psi_{1}
$$


$\psi_{1}$ - a proportionality coefficient.

This equation becomes a dependence:

$$
K_{o d}=0,004 \cdot h \text { and } h=250 \cdot K_{o d}
$$

The coefficient $\left(K_{\mathrm{od}}\right)$ is $0.1 ; 0.15$ and 0.2 . The height of the stand $(h)$ is $25 ; 37.5 ; 50 \mathrm{~cm}$. The biomass formed in the plant community $\left(q_{\mathrm{p}}\right)$ will be respectively equal to $0.079 I_{0}$; $0.088 I_{0}$ and $0.079 I_{0}$. If the coefficient $K_{\text {od }}=0$ and $K_{\text {od }}=0.34, q_{\mathrm{p}}=0$. In the first case, because of $K_{\text {od }}=0$, in the second, because of $I_{0}=0$. There is a dependence of the productive component on the light load in the plant community, the graph in Figure 1has a parabolic character and one maximum.

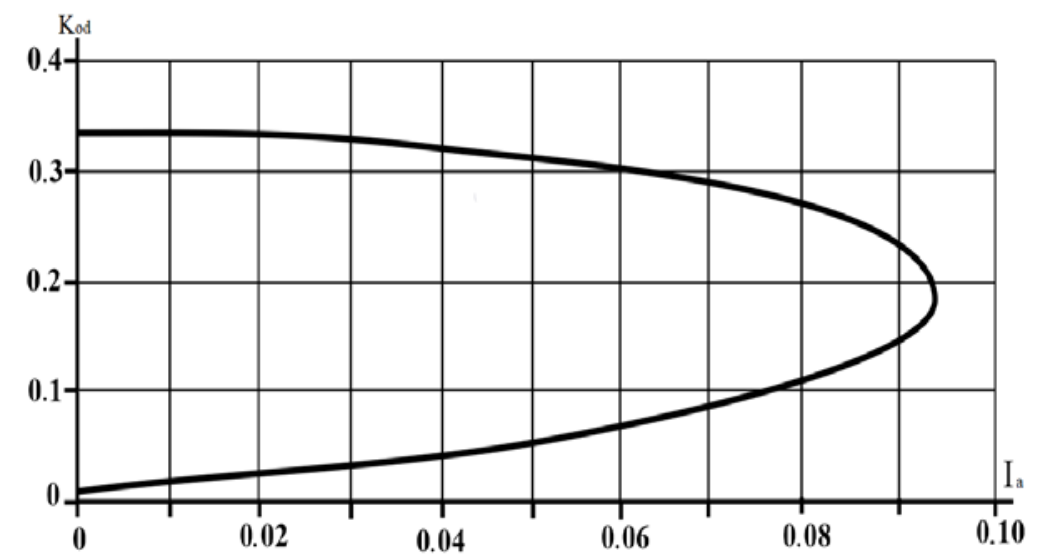

Fig. 1. The dependence of the productive component on the coefficient of optical density of the plant community $\left(K_{\mathrm{od}}\right) . I_{\mathrm{a}}$ - a light load for the growing season in the Volgograd region.

In Table 1 the photosynthetically active radiation (PAR) is located within 0.72-0.75 cal / $\mathrm{cm}^{2} \cdot \mathrm{min}$ in the Volgograd region. The radiation balance (B) is $1.24-1.26 \mathrm{cal} / \mathrm{cm}^{2} \cdot \mathrm{min}$. The direct radiation $(\mathrm{S})$ reaches $1.22 \mathrm{cal} / \mathrm{sm}^{2} \cdot \min$, the scattered radiation $(\mathrm{D})-0.34-0.39$ $\mathrm{cal} / \mathrm{sm}^{2} \cdot \min$, the reflected radiation $\left(\mathrm{R}_{\mathrm{k}}\right)-0.32-0.36 \mathrm{cal} / \mathrm{sm}^{2} \cdot \min$.

Table 1. The average values of solar radiation balance and photosynthetically active solar radiationon the example of sowing winter wheat.

\begin{tabular}{|c|c|c|c|c|}
\hline \multirow{2}{*}{ Index } & \multicolumn{4}{|c|}{ Distance from the forest strip, $\mathrm{H}$} \\
\cline { 2 - 5 } & $1,5 \mathrm{H}$ & $5 \mathrm{H}$ & $10 \mathrm{H}$ & $3 \mathrm{H}$ \\
\hline $\mathrm{B}, \mathrm{cal} / \mathrm{sm}^{2} \cdot \mathrm{min}$ & 1.25 & 1.26 & 1.25 & 1.24 \\
\hline $\mathrm{S}, \mathrm{cal} / \mathrm{sm}^{2} \cdot \mathrm{min}$ & 1.22 & 1.21 & 1.22 & 1.22 \\
\hline $\mathrm{D}, \mathrm{cal} / \mathrm{sm}^{2} \cdot \mathrm{min}$ & 0.39 & 0.37 & 0.34 & 0.34 \\
\hline $\mathrm{R}_{\mathrm{k}}, \mathrm{cal} / \mathrm{sm}^{2} \cdot \mathrm{min}$ & 0.36 & 0.32 & 0.33 & 0.32 \\
\hline $\mathrm{PAR}, \mathrm{cal} / \mathrm{sm}^{2} \cdot \mathrm{min}$ & 0.74 & 0.74 & 0.72 & 0.75 \\
\hline
\end{tabular}

In Figure 2 the data processing showed a slight difference between the calculated and experimental data. 


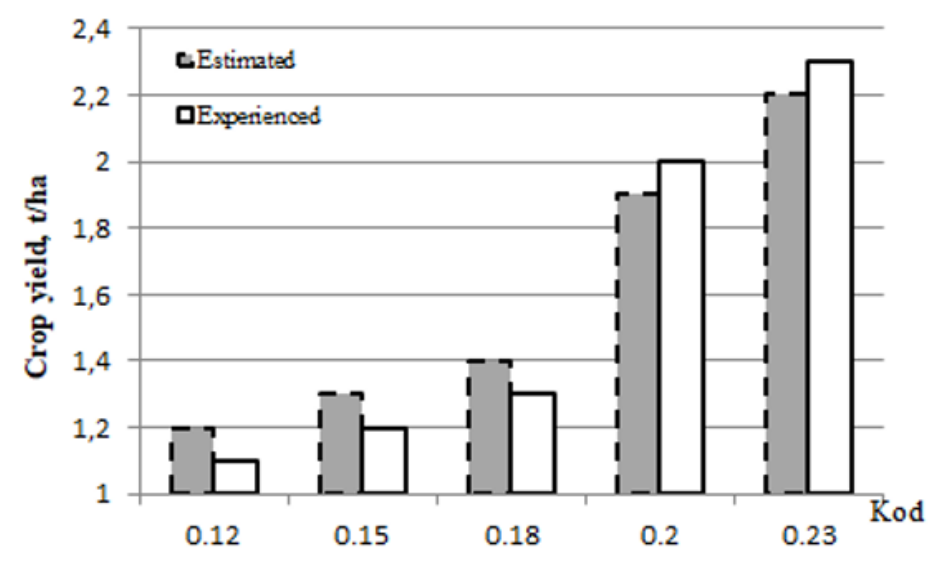

Fig. 2. The dependence of the crop yield of winter wheat (t/ha) on the coefficient of optical density of the plant screen, $K_{\text {od }}$.

The investigated object has a continuous vegetation screen. The vegetation cover of natural phytocenoses has a curtain character. Therefore, the degree of projective cover should be considered. The difference in the calculation shifts the phytoproductivity value. In this case, the optical density coefficient will be lower:

$$
K_{o d . n}=K_{p c} \cdot K_{c}
$$

$K_{\text {od.n }}, K_{\mathrm{c}}-$ an optical density coefficients of natural phytocenoses;

$K_{\mathrm{pc}}-\mathrm{a}$ cover ratio (in shares, 1 unit);

$K-$ a curtains of natural phytocenoses.

\section{Conclusion}

The solar activity affects the formation of plant biomass. It directly depends on the penetration of the light flux through the inside of the vegetation cover. The intensity of the formation of organic matter depends on the area of the assimilation apparatus of plants (aboveground phytomass). Optimal climatic conditions for plant growth are not always a positive factor. Highly compacted crops can have a negative role in biomass development. Therefore, it is necessary to strive for the optimum ratio of the light load and the area of its reception.

The radiation maximum in the dry steppe conditions of the Volgograd region reaches $1.26 \mathrm{cal} / \mathrm{cm}^{2} \cdot \min$., the photosynthetically active radiation (PAR) is located within $0.72-$ $0.75 \mathrm{cal} / \mathrm{cm}^{2} \cdot \min$. The scattered radiation reaches $0.34-0.39 \mathrm{cal} / \mathrm{cm}^{2} \cdot \min$. The reflected radiation is $0.32-0.36 \mathrm{cal} / \mathrm{cm}^{2} \cdot \mathrm{min}$. The radiation reduction factor, taking into account the curvature of the coating, should be no more than 0.25 . The coefficient $K_{\text {od }}$ should be close to one. As a result, the sunllight radiation (PAR) will reach about $2.5 \%$.

The authors want to thank Yuri Vasiliev for the scientific and technical assistance provided throughout all the experiment.

\section{References}

1. A. Rosati, K.J. Wolz, S. Jose Modeling light below tree canopies overestimates net 
photosynthesis and radiation use efficiency in understory crops by averaging light in space $\begin{array}{lllll}\text { and time Agricultural and Forest Meteorology } 284 & 107892\end{array}$ doi.org/10.1016/j.agrformet.2019.107892 (2020).

2. N. I. Buyankin, A. G. Krasnoperov, Z. N. Fedorova Optimal'nye sroki letnih posevov sredoobrazuyushchih kul'tur $\mathrm{v}$ zavisimosti ot vysoty solncestoyaniya i kolichestva osadkov AgroEkoInfo 3(19) 2 (2015).

3. Yu. I. Vasiliev, T. V. Voloshenkova, N. N. Ovechko Metodologiya prognoza var'irovaniya urozhaya zernovyh kul'tur v agrolesolandshafte v svyazi s nestabil'nost'yu klimaticheskih harakteristik Russian Agricultural 4 54-57 (2013).

4. M. V. Vlasenko, K. Yu. Trubakova Vodnyj rezhim vidov semejstva Poaceae v usloviyah zasuhi Agrarian Bulletin of the Urals 11(190) 2-8 DOI: 10.32417/article_5dcd861eb7f0a4.35513022 (2019).

5. M. Zhangab, Y. Gaoa, Y. Zhanga, T. Fischerb etc. The contribution of spike photosynthesis to wheat yield needs to be considered in process-based crop models Field Crops Research 257107931 doi.org/10.1016/j.fcr.2020.107931 (2020).

6. A G. Molchanov Izmenchivost' svetovyh krivyh fotosinteza nekotoryh drevesnyh porod Contemporary Problems of Ecology 1 20-26 (2015).

7. A. G. Molchanov Fiziologicheskie issledovaniya drevesnyh rastenij Forestry information 4 23-31 (2019).

8. A. N. Sazhin, K. N. Kulik, Yu. I. Vasil'ev Pogoda i klimat Volgogradskoj oblasti Volgograd: VNIALMI 333 (2017).

9. P. A. Shary, L. S. Sharaya, T. M. Lysenko Influence of Solar Radiation on the Distribution of Halophytes in Plant Communities Russ $J$ Ecol. 51 329-336 https://doi.org/10.1134/S1067413620040104 (2020).

10. Yu. I. Stozhkov, G. A. Bazilevskaya, V. S. Makhmutov, N. S. Svirzhevsky, A. K. Svirzhevskaya, V. I. Logachev, V. P. Okhlopkov Cosmic rays, solar activity, and changes in the earth's climate Bulletin of the Russian Academy of Sciences: Physics. 81(2) 252-254 (2017).

11. S. Yu. Turko, K. Yu. Trubakova Intensivnost' formirovaniya travostoya na imitacionnyh modelyah pastbishch razlichnogo sezona ispol'zovaniya Agrarian Bulletin of the Urals 11(202) 37-44 DOI: 10.32417/1997-4868-2020-202-11-37-44 (2020).

12. S. Yu. Turko, K. Yu. Trubakova Dolgosrochnyj prognoz pogodnyh uslovij kak instrument planirovaniya stabil'nogo rosta i razvitiya rastenij na pastbishche Proceedings of Nizhnevolzskiy agrouniversity complex: science and higher vocational education 4(27) 4247 (2020). 